\title{
Bending properties of Laminated Veneer Lumber produced from Keruing (Dipterocarpus sp.) reinforced with low density wood species
}

\begin{abstract}
Low density wood such as Pulai (Alstonia sp.), Sesendok (Endospermum sp.) and Kekabu Hutan (Bombax sp.) have never been regarded as structural material due to their inferior strengths. Converting these timbers into Laminated Veneer Lumber (LVL) and reinforcing them with stronger timber could turn them into much sought after materials. This study discusses the effects of incorporating Keruing veneers into LVL panels made from low density wood. Laminated Veneer Lumber comprised 11-ply and 15-ply veneers fabricated by arranging Keruing veneers located at the surface and the low density woods were arranged as core. Phenol Formaldehyde (PF) resin was used as the binder. The LVLs were subjected to cyclic boil-dry test according to voluntary product Standard PS1-95: Construction and Industrial Plywood. The bending properties and percent delamination were determined according to the Japanese Agricultural Standard (JAS) for Structural LVL: 1993 before and after the cyclic boil dry treatment. Result showed through incorporating low density wood with Keruing veneers, both 11-ply and 15-ply LVL panels achieved the minimum requirements for various grades stipulated in the JAS for Structural LVL Standard: 1993. At the same panel thickness, 15-ply LVL shows a better performance compares to those of 11ply LVL. Presence of Keruing veneers as surface layers significantly increased the strength of the LVL panels. All panels passed the delamination test stipulated on the JAS for Structural LVL: 1993. Conclusively, combining Keruing and the low density wood veneers in LVL fabrication gave greater strength and more stable material.
\end{abstract}

Keyword: Laminated veneer lumber; Keruing; Low density wood; Cyclic boil dry 